\title{
Protective and inhibitory effects of acteoside from Abeliophyllum distichum Nakai against oxidative DNA damage
}

\author{
TAE WON JANG ${ }^{1}$, JI SOO CHOI ${ }^{2}$ and JAE HO PARK ${ }^{2,3}$ \\ ${ }^{1}$ Department of Medicinal Plant Resources, Andong National University, Andong, Geongsangbuk 36729; \\ Departments of ${ }^{2}$ Medicinal Plant Science and ${ }^{3}$ Pharmaceutical Science, Jungwon University, \\ Geosan, Chungcheongbuk 28024, Republic of Korea
}

Received January 2, 2020; Accepted June 8, 2020

DOI: $10.3892 / \mathrm{mmr} .2020 .11258$

\begin{abstract}
Abeliophyllum distichum Nakai is a Korean endemic plant of the Oleaceae family that contains acteoside, a glycosylated caffeic acid, with neuroprotective, anti-inflammatory and antibacterial properties. Previous studies, involving Accelerated Chromatographic Isolation, a high-performance liquid chromatography-photodiode array detector and a liquid chromatograph-mass selective detector, isolated and identified acteoside in A. distichum (AAD) and documented its antioxidant and anti-inflammatory activities. The aim of the present study was to determine whether AAD could protect from DNA damage by reducing oxidative stress. AAD treatment protected plasmid DNA against damage to DNA double-strands induced by reactive oxygen species (ROS) and decreased the levels of phosphorylated p53 and $\gamma$-H2AX in ROS-treated NIH 3T3 cells. These findings suggested that AAD could reduce ROS-mediated cellular damage and may represent an effective, natural antioxidant with the ability to protect genetic material.
\end{abstract}

\section{Introduction}

Molecules obtained from medicinal plants have traditionally been used by people to maintain good health. According to the World Health Organization, $>80 \%$ of the world's population use traditional medicinal plants to improve their health (1). A previous study has suggested that medicinal plants contain chemical components and exhibit biological activities that are useful for physiological processes including antioxidant, anti-inflammation and anti-cancer activity in the body (2). The most widely used of these plant bioactive components are alkaloids, flavonoids and phenolic compounds $(3,4)$. Due

Correspondence to: Professor Jae Ho Park, Department of Pharmaceutical Science, Jungwon University, 85 Munmu-ro, Geosan, Chungcheongbuk 28024, Republic of Korea

E-mail: parkjh@jwu.ac.kr

Key words: Abeliophyllum distichum, acteoside, oxidative damage, p53 to their aromatic structure, phenolic compounds can act as electron donors, and this antioxidant potential can relatively reduce reactive oxygen species (ROS) levels (5). DNA is under constant stress resulting from environmental factors or cellular metabolism (6). ROS cause DNA damage through oxidative stress, thereby playing an important role in tumor initiation (7). In response to DNA damage, cells activate complex signaling networks to either repair the damage or promote cell death (8). Oxidative DNA damage has been implicated in the pathogenesis of several diseases including cancer, inflammation, and heart disease (9). Thus, it is important for organisms to suppress the excessive generation of ROS.

ROS-mediated DNA damage influences cell survival through the modification of histone H2AX (10-14). The tumor suppressor $\mathrm{p} 53$ regulates baseline and DNA damage-inducible levels of ROS (15-17). p53 prevents DNA damage through an activated phosphatidylinositol 3-kinase-related kinase (PI3K) that plays a pivotal role in activating DNA repair proteins (18). Phosphorylated H2AX $(\gamma-\mathrm{H} 2 \mathrm{AX})$ serves an important role in the DNA damage response to oxidative stress by recruiting genes involved in DNA repair (19). Biological processes that eliminate ROS are important in the DNA damage response and in preventing the progression of numerous diseases (20).

Abeliophyllum distichum Nakai is a deciduous flowering plant belonging to the Oleaceae family. A. distichum is a monotypic genus and has been regarded as one of the important plant resources for research on its genetic property and bioactivity (21). Additionally, it is known to contain some glycosides including acteoside, isoacteoside, rutin and hirsutrin (22). Acteoside exhibits several pharmacological properties such as anti-hepatotoxic (23), anti-inflammatory (24), antinociceptive (25) and antioxidant activities (26-28). It also improves sexual function (29). However, to the best of our knowledge, whether acteoside from A. distichum (AAD) can prevent oxidative DNA damage remains unknown. Therefore, the aim of the present study was to determine whether AAD could exert a protective effect over oxidative DNA damage.

\section{Materials and methods}

Plant material and extraction. A. distichum Nakai [voucher no. Park1001(ANH)] was collected from the Misun-Hyang Theme Park. An extract from air-dried A. distichum was 
obtained by immersion in $80 \%$ methanol for 3 days and a using a sonicator $(40 \mathrm{KHz} ; 00 \mathrm{~W}$; Hwashin Technology Co., Ltd.). The methanol-soluble extracts were filtered and concentrated using an $\mathrm{N}-1110 \mathrm{~S}$ vacuum evaporator (Eyela). The extracts were sequentially fractionated three times with 1:1 ratio of petroleum ether, 1:1 ratio of chloroform and 1:1 ratio of ethyl acetate. The ethyl acetate fraction from A. distichum was harvested and refrigerated at $4^{\circ} \mathrm{C}$ until use.

Isolation and purification. Acteoside was isolated from the ethyl acetate fraction (500 g) of A. distichum using an Isolera ${ }^{\mathrm{TM}}$ Spektra Accelerated Chromatographic Isolation system at $25^{\circ} \mathrm{C}$ with SNAP KP-SIL (100 g; 170x40 mm) and SNAP Ultra (25 g; 80 x $35 \mathrm{~mm}$ ) cartridges (both from Biotage AB). The mobile phases consisted of chloroform (solvent A) and methanol (solvent B). The flow rate was kept at $50 \mathrm{ml} / \mathrm{min}$ for a total run volume of $1,600 \mathrm{ml}$.

The system was run with a gradient program: 0-32 $\mathrm{min}$, $6-50 \% \mathrm{~B}$ and the peaks of interest were monitored at $335 \mathrm{~nm}$ by a photodiode array (PDA) detector with SNAP KP-SIL cartridges. Subsequently, using the same mobile phases, the flow rate was kept constant at $75 \mathrm{ml} / \mathrm{min}$ for a total run volume of $600 \mathrm{ml}$. Then the system was run with a gradient program: 0-32 min, 6-50\% B and the peaks of interest were monitored at $335 \mathrm{~nm}$ by a PDA detector using SNAP Ultra cartridges. Lastly, $2.5 \mathrm{~g}$ AAD was further analyzed by high-performance liquid chromatography (HPLC)-PDA and liquid chromatography-mass spectrometry (LC-MS) for further analysis and identification.

Identification of acteoside by HPLC analysis. AAD (1 mg/ml) was analyzed in a Waters 2695 HPLC system equipped with Waters 2996 PDA using an Xbridge-C18 column (250x4.6 mm; $5 \mu \mathrm{m}$; all from Waters Corporation). The binary mobile phase consisted of acetonitrile (solvent A) and water containing 1\% acetic acid (solvent B). Both solvents were filtered through a $0.45-\mu \mathrm{m}$ filter prior to use. The flow rate was kept constant at $1.0 \mathrm{ml} / \mathrm{min}$ for a total run time of $40 \mathrm{~min}$ at $25^{\circ} \mathrm{C}$. The system was run with a gradient program: i) $0-5 \mathrm{~min}, 10-15 \% \mathrm{~A}$ : $90-85 \% \mathrm{~B}$; ii) $5-15 \mathrm{~min}, 15 \% \mathrm{~A}: 85 \% \mathrm{~B}$; iii) $15-40 \mathrm{~min}$, $15-40 \%$ A: $85-60 \%$ B. The sample injection volume was $10 \mu \mathrm{l}$. The peaks of interest were monitored at $335 \mathrm{~nm}$ by a PDA and compared with an acteoside standard (V4015-10MG; Sigma-Aldrich; Merck KGaA).

Identification of acteoside by LC-MS. LC-MS analysis was performed using a Nexera X2 Ultra high-performance liquid chromatograph/mass selective detector at $25^{\circ} \mathrm{C}$, equipped with an LCMS-8050 quadrupole mass spectrometer (all from Shimadzu Corporation). The liquid chromatographic system consisted of a binary pump, on-line vacuum degasser and thermostatic column compartment, connected in-line to the mass spectrometer. Data acquisition and analysis were carried out using Shimadzu LabSolutions 5.0 (Shimadzu Corporation). Samples $(3 \mu 1)$ were injected into the HPLC system using a binary gradient of deionized water (solvent $\mathrm{A}$ ) and acetonitrile (solvent B) and isocratically eluted in 50\% solvent B for $1 \mathrm{~min}$ at a flow rate of $0.3 \mathrm{ml} / \mathrm{min}$. The mass spectrometer was fitted to an atmospheric pressure electrospray ionization source operated in negative ion mode. The electrospray capillary voltage was set to $4.0 \mathrm{kV}$, with a nebulizing gas (10.7 bar) flow rate of $3 \mathrm{l} / \mathrm{min}$ and a drying gas temperature of $300^{\circ} \mathrm{C}$. MS data were acquired in the Scan mode (mass range m/z 300-800) and the Product ion scan mode.

1,1-Diphenyl-2-picryl hydrazyl (DPPH) radical scavenging activity. DPPH radical scavenging activity was measured as previously described (30), with minor modifications. A $300 \mu \mathrm{M}$ DPPH solution (Sigma-Aldrich; Merck KGaA) in $95 \%$ alcohol was prepared. The solution was adjusted to an absorbance value of 1.00 at $515 \mathrm{~nm}$. A $40-\mu 1$ volume of sample was mixed with $760 \mu \mathrm{l}$ DDPH solution, then incubated for $20 \mathrm{~min}$ in the dark at $25^{\circ} \mathrm{C}$. L-ascorbic acid was used as a positive control. Absorbance was measured at $515 \mathrm{~nm}$ using an ultraviolet (UV)/visible spectrophotometer (Xma-3000PC; Human Corporation). The radical scavenging activity was measured as a decrease in the absorbance of DPPH and calculated using the following formula:

DPPH radical scavenging activity $(\%)=\left[1-\left(\mathrm{A}_{\text {Sample }^{-}}\right.\right.$ $\left.\left.\mathrm{A}_{\text {Blank }}\right) / \mathrm{A}_{\text {Control }}\right] \times 100$ where ' $\mathrm{A}_{\text {Sample }}$ '=Absorbance values ofDPPH radicals following treatment with sample, ' $\mathrm{A}_{\mathrm{Blank}}$ ' = Absorbance values of ethanol and ' $\mathrm{A}_{\mathrm{Control}}$ ' $=$ Absorbance values of DPPH radicals.

\section{2,2'-Azino-bis (3-ethylbenzothiazoline-6-sulfonic acid)} diammonium salt (ABTS) radical scavenging activity. ABTS radical scavenging activity was measured as previously described (31), with some modifications. A $7.4 \mathrm{mM}$ ABTS and $2.6 \mathrm{mM}$ potassium persulfate solution (both from Sigma-Aldrich; Merck KGaA) in distilled water was prepared $24 \mathrm{~h}$ prior to use. The solution was adjusted to an absorbance value of 0.70 at $732 \mathrm{~nm}$. A $40 \mu \mathrm{l}$ volume of sample was mixed with $760 \mu \mathrm{l}$ ABTS solution, then incubated for $20 \mathrm{~min}$ in the dark at $25^{\circ} \mathrm{C}$. L-ascorbic acid was used as a positive control. Absorbance was measured using a UV/visible spectrophotometer at $732 \mathrm{~nm}$. The radical scavenging activity was measured as a decrease in the absorbance of ABTS and calculated using the following formula: ABTS radical scavenging activity (\%) $=\left[1-\left(\mathrm{A}_{\text {Sample }}-\mathrm{A}_{\text {Blank }}\right) / \mathrm{A}_{\text {Control }}\right] \times 100$ where ' $\mathrm{A}_{\text {Sample }}$ ' = Absorbance values of ABTS radicals after treatment with sample, ' $\mathrm{A}_{\mathrm{Blank}}$ ' = Absorbance values of $\mathrm{H}_{2} \mathrm{O}$ and ' $\mathrm{A}_{\text {Control }}$ ' = Absorbance values of ABTS radicals.

Inhibitory effect of $A A D$ on oxidative DNA damage using $\Phi X-174$ RF I plasmid DNA. The inhibitory effect on oxidative DNA damage was measured as previously described (32). Conversion of supercoiled plasmid DNA to open circular forms has been used as an index of DNA damage (32). In the absence of $\mathrm{OH}^{-}$radicals and $\mathrm{Fe}^{2+}$ ions, plasmid DNA mainly exists in a supercoiled form. However, in the presence of $\mathrm{OH}^{-}$radicals and $\mathrm{Fe}^{2+}$, plasmid DNA is cleaved, converting its supercoiled form into open-circular forms. AAD $(0-200 \mu \mathrm{M})$ was pre-incubated with $5 \mathrm{mM} \mathrm{FeCl}_{2}$ or $0.4 \mathrm{mM} \mathrm{FeSO}_{4}+0.4 \mathrm{mM} \mathrm{H}_{2} \mathrm{O}_{2}$ for $15 \mathrm{~min}$ at $25^{\circ} \mathrm{C}$. The $\Phi \mathrm{X}-174 \mathrm{RF}$ I plasmid DNA $(50 \mu \mathrm{g} / \mathrm{ml}$; Promega Corporation) was then added to the mixtures. A solution containing $50 \%$ glycerol (v/v), $40 \mathrm{mM}$ EDTA, and $0.05 \%$ bromophenol blue (Sigma-Aldrich; Merck KGaA) was added to stop the reaction. Reaction mixtures were analyzed by agarose gel electrophoresis on $1 \%$ gels with DNA SafeStain (Lamda Biotech). DNA in the gel was 
Table I. Primer sequences.

A, RT-semi-qPCR

\begin{tabular}{lll}
\hline Gene & Forward primer sequence (5'-3') & Reverse primer sequence (5'-3') \\
\hline H2AX & TTGCTTCAGCTTGGTGCTTAG & AACTGGTATGAGGCCAGCAAC \\
p53 & CGGATAGTATTTCACCCTCAAGATCCG & AGCCCTGCTGTCTCCAGACTC \\
GAPDH & AACTTTGGCATTGTGGAAGG & ATGCAGGGATGATGTTCTGG \\
\hline
\end{tabular}

B, RT-qPCR

\begin{tabular}{lll}
\hline Gene & Forward primer sequence (5'-3') & Reverse primer sequence (5'-3') \\
\hline H2AX & GCGTCTTTGCTTCAGCTTG & CACACTGGCCTACGAATGG \\
p53 & GATGTTCCGGGAGCTGAAT & GCCCCACTTTCTTGACCAT \\
GAPDH & CCTCCAAGGAGTAAGAAACC & CTAGGCCCCTCCTGTTATTA \\
\hline
\end{tabular}

RT, reverse transcription; qPCR, quantitative PCR; H2AX, H2A histone family member X.

visualized using the Chemi-Doc imaging system (Bio-Rad Laboratories, Inc.) controlled by Image Lab software 6.0 (Bio-Rad Laboratories, Inc.).

Cell culture. The murine skin fibroblast cell line NIH 3T3 was purchased from American Type Culture Collection. Cells were cultured under sterile conditions at $37^{\circ} \mathrm{C}$ in a humid incubator with $5 \%$ of $\mathrm{CO}_{2}$, in Dulbecco's modified Eagle's medium supplemented with $10 \%$ bovine calf serum (Biowest), $1 \%$ antibiotics (penicillin/streptomycin; HyClone; Cytiva) and $0.2 \%$ anti-mycoplasma agents (Plasmocin prophylactic; InvivoGen). The oxidative damage was induced by $150 \mu \mathrm{M}$ $\mathrm{FeSO}_{4}+600 \mu \mathrm{M} \mathrm{H}_{2} \mathrm{O}_{2}$ for the cell viability, western blotting, and PCR assays.

Cell viability. Cells $\left(1.0 \times 10^{4}\right.$ cells $\left./ \mathrm{ml}\right)$ were treated with AAD $(0-200 \mu \mathrm{g} / \mathrm{ml})$ and incubated at $37^{\circ} \mathrm{C}$ for $24 \mathrm{~h}$. After $24 \mathrm{~h}$, cells were treated with $10 \mu \mathrm{l}$ alamarBlue ${ }^{\circledR}$ cell viability reagent (Thermo Fisher Scientific, Inc.). After 2 h, cell viability was measured using a UV/Visible spectrophotometer at $570 \mathrm{~nm}$.

Immunoblotting. Cells were lysed using radioimmunoprecipitation assay buffer (Thermo Fisher Scientific, Inc.) supplemented with a protease inhibitor cocktail (Sigma-Aldrich; Merck KGaA). The protein concentration in the sample was determined using the Bradford protein assay (Bio-Rad Laboratories, Inc.). Proteins $(20 \mu \mathrm{g})$ were separated by SDS-PAGE on $10 \%$ gels, then transferred to a PVDF (Bio-Rad Laboratories, Inc.). The membrane was blocked for $1 \mathrm{~h}$ at $20^{\circ} \mathrm{C}$ with $5 \%$ bovine serum albumin (BSA; Biosesang) in TBS containing $1 \%$ Tween-20 (TBS-T), then incubated with primary antibodies in $3 \% \mathrm{BSA}$ overnight at $4^{\circ} \mathrm{C}$. The following primary antibodies were used at 1:1,000 (all from Abcam): i) Anti- $\gamma \mathrm{H} 2 \mathrm{AX}$ (Ser139) polyclonal antibody (cat. no. ab11174); ii) anti-H2AX polyclonal antibody (cat. no. ab11175); iii) anti-phosphorylated-p53 (p-p53; Ser15) polyclonal antibody (cat. no. ab1431); iv) anti-p53 polyclonal antibody (cat. no. ab131442); and v) anti-GAPDH monoclonal antibody (cat. no. ab8245). After washing with TBS-T, membranes were incubated with anti-rabbit IgG monoclonal antibody (cat. no. 18-8816-33; Rockland Immunochemicals Inc.; 1:5,000) or anti-mouse IgG monoclonal antibody (cat. no. 18-8817-33; Rockland Immunochemicals Inc.; 1:5,000) horseradish peroxidase-conjugated secondary antibodies for $1 \mathrm{~h}$. Immunoreactive bands were visualized using an ECL western blotting substrate and the Chemi-Doc imaging system (both from Bio-Rad Laboratories, Inc.). Bands were analyzed using the ImageJ software v1.51K (National Institutes of Health).

Reverse transcription (RT)-semi-quantitative PCR (qPCR). Total RNA was extracted from NIH 3T3 cells using the NucleoSpin $^{\mathrm{TM}}$ RNA Plus kit (Macherey-Nagel; Thermo Fisher Scientific, Inc.). cDNA was synthesized using ReverTra Ace- $\alpha_{-}{ }^{\mathrm{TM}}$ (Toyobo Life Science), according to the manufacturer's protocol. qPCR was carried out using Quick $\mathrm{Taq}^{\circledR}$ HS Dye Mix (Toyobo Life Science). Amplification was initiated at $94^{\circ} \mathrm{C}$ for $2 \mathrm{~min}$, followed by 30 amplification cycles at $94^{\circ} \mathrm{C}$ for $30 \mathrm{sec}$ (denaturation), then $54.2^{\circ} \mathrm{C}$ for $30 \mathrm{sec}$ (annealing/extension) using Thermal cycler (T100 ${ }^{\mathrm{TM}}$; Bio-Rad Laboratories, Inc.). Primer sequences using Primer 3 program 0.4.0 (http://bioinfo.ut.ee/primer3-0.4.0/) are presented in Table I. DNA density was visualized by $2 \%$ agarose gel (A1200; Biosesang) with 1\% DNA SafeStain (C138; Lamda Biotech Corporation). Transcription levels were normalized to GAPDH. Density was analyzed using the ImageJ software 1.51K (National Institutes of Health).

$R T$ - $q P C R$ analysis. cDNA samples were generated using the aforementioned method. qPCR was carried out using the Quanti Tect ${ }^{\circledR}$ SYBR-Green PCR kit (Qiagen GmbH) on a 7500 Real-Time PCR system (Applied Biosystems; Thermo Fisher Scientific, Inc.). Primers were designed using the Primer 3 program 0.4.0 (http://bioinfo.ut.ee/primer3-0.4.0/; Table I). Thermocycling conditions consisted of a $15-\mathrm{min}$ initial denaturation at $95^{\circ} \mathrm{C}$, followed by 40 amplification cycles at $94^{\circ} \mathrm{C}$ for $15 \mathrm{sec}$ (denaturation), $60^{\circ} \mathrm{C}$ for $30 \mathrm{sec}$ (annealing) and $72^{\circ} \mathrm{C}$ for $30 \mathrm{sec}$ (extension). 

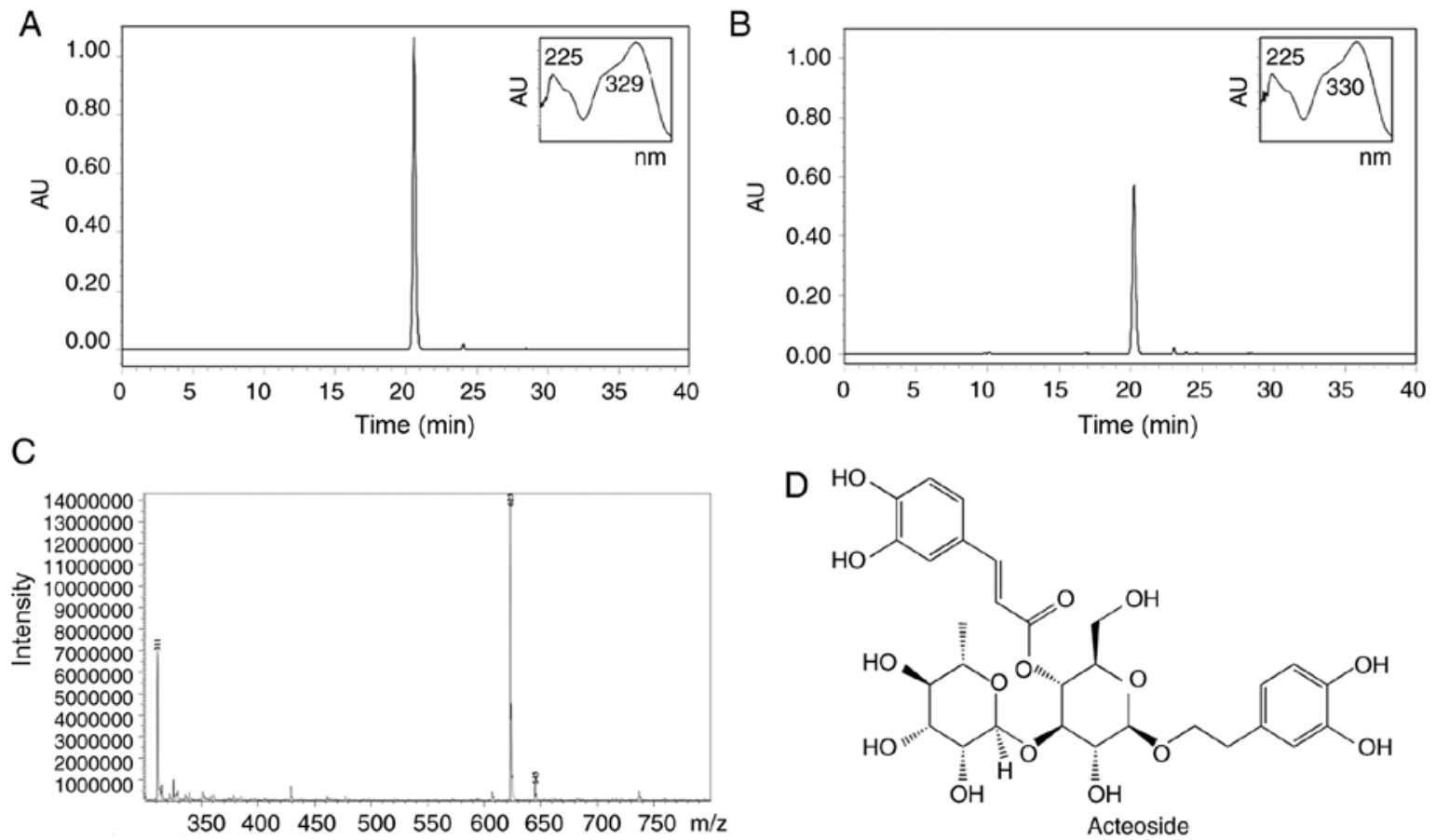

Figure 1. HPLC chromatograms and structure of AAD. (A) HPLC chromatogram and UV-spectra of AAD. (B) HPLC chromatogram and UV-spectra of standard acteoside. (C) LC-MS spectra of AAD with m/z 623. (D) Structure of acteoside. AAD, acteoside from Abeliophyllum distichum; AU, arbitrary units; HPLC, high-performance liquid chromatography; UV, ultraviolet.

Transcription levels were normalized to GAPDH. The $2^{-\Delta \Delta \mathrm{Cq}}$ formula was used to analyze mRNA expression levels, where $\Delta \Delta \mathrm{Cq}=\left(\mathrm{Cq}_{\text {target }}-\mathrm{Cq}_{\mathrm{GAPDH}}\right)_{\text {sample }}-\left(\mathrm{Cq}_{\text {target }}-\mathrm{Cq}_{\mathrm{GAPDH}}\right)_{\text {control }}(33)$. Data were analyzed using the ABI 7500 Software 2.3 (Applied Biosystems; Thermo Fisher Scientific, Inc.).

Immunofluorescence staining. $\gamma-\mathrm{H} 2 \mathrm{AX}$ and $\mathrm{p}-\mathrm{p} 53$ are markers for DNA damage and repair (34). NIH 3T3 cells were treated with $\mathrm{AAD}(0,100 \mu \mathrm{M})$ and oxidative damage $\left(150 \mu \mathrm{M} \mathrm{FeSO}_{4}+600 \mu \mathrm{M} \mathrm{H}_{2} \mathrm{O}_{2}\right)$ at $37^{\circ} \mathrm{C}$ for $24 \mathrm{~h}$. Following treatment, samples were prepared on sterilized glass coverslips (BD Biosciences). Cells were then fixed with $4 \%$ paraformaldehyde for $15 \mathrm{~min}$ at $20^{\circ} \mathrm{C}$, then blocked for $1 \mathrm{~h}$ with $3 \% \mathrm{BSA}$ (Biosesang) and $0.1 \%$ Triton X-100 for permeabilization at $20^{\circ} \mathrm{C}$. Cells were incubated with anti- $\gamma-\mathrm{H} 2 \mathrm{AX}$ (cat. no. ab11174; 1:500) and anti-p-p53 (cat. no. ab1431; 1:500) overnight at $4^{\circ} \mathrm{C}$, then with Alexa Fluor 488 (cat. no. ab150077; 1:500) and Alexa Fluor 568-conjugated secondary antibodies (cat. no. ab175471; 1:500; All antibodies from Abcam) for an additional $1 \mathrm{~h}$ at $20^{\circ} \mathrm{C}$ in the dark. Nuclei were stained using DAPI (Invitrogen; Thermo Fisher Scientific, Inc.) at $37^{\circ} \mathrm{C}$. Slides were mounted and images captured using a CKX53 fluorescence microscope (magnification, x400; Olympus Corporation).

Statistical analysis. All data were analyzed using GraphPad Prism 5.0 (GraphPad Software, Inc.) and are presented as the mean \pm standard deviation. All experiments were performed $\geq 3$ times. Data of DPPH and ABTS radical scavenging activity were analyzed using paired Student's t-test. Other data were analyzed by One-way ANOVA followed by Tukey's post hoc test were used to compare the means across multiple groups. $\mathrm{P}<0.05$ was considered to indicate a statistically significant difference.

\section{Results}

Isolation, purification and identification of $A A D$. Acteoside standard and AAD extract were analyzed using HPLC-PDA. The standard (Fig. 1A) and the sample (Fig. 1B) displayed similar retention times $(20.3 \mathrm{~min})$ and UV spectra. The LC-MS data (Fig. 1C) also exhibited $623 \mathrm{~m} / \mathrm{z}\left(\mathrm{M}-\mathrm{H}^{-}\right)$. Based on these observations, the AAD sample was identified as an acteoside (Fig. 1D). The purity of AAD was $>95 \%$, based on a calibration curve $\left(\mathrm{y}=16089 \mathrm{x}-93989, \mathrm{R}_{2}=0.9971\right)$.

Antioxidant activity of AAD. AAD eliminated DPPH radicals in a dose-dependent manner (Fig. 2A). DPPH radicals were scavenged at all AAD concentrations, except $0.32 \mu \mathrm{M}$, although not to the same extent as with L-ascorbic acid. The half-maximal inhibitory concentration $\left(\mathrm{IC}_{50}\right)$ values of AAD and L-ascorbic acid were 8.81 and $5.08 \mu \mathrm{g} / \mathrm{ml}$, respectively. Similarly, AAD also eliminated ABTS radicals in a dose-dependent manner (Fig. 2B). The $\mathrm{IC}_{50}$ values of $\mathrm{AAD}$ and L-ascorbic acid were 6.47 and $10.49 \mu \mathrm{g} / \mathrm{ml}$, respectively. Furthermore, at concentrations of 8 and $40 \mu \mathrm{M}$, the scavenging activity of AAD was significantly higher compared with L-ascorbic acid. These results indicated that AAD effectively scavenged DPPH and ABTS radicals in vitro.

Protective effect against oxidative stress-induced DNA damage of $A A D$. The protective effects of AAD on oxidative DNA damage were evaluated in a DNA cleavage assay using $\Phi X-174$ RF I DNA. The untreated control group (lane 1) was used as a positive control and assigned an open circular (OC) DNA band density value of $100 \%$. In lane 2, the groups receiving $\mathrm{Fe}^{2+}$ or $\mathrm{OH}^{-}$without $\mathrm{AAD}$ treatment were used as a negative control and given a value of $0 \%$. 

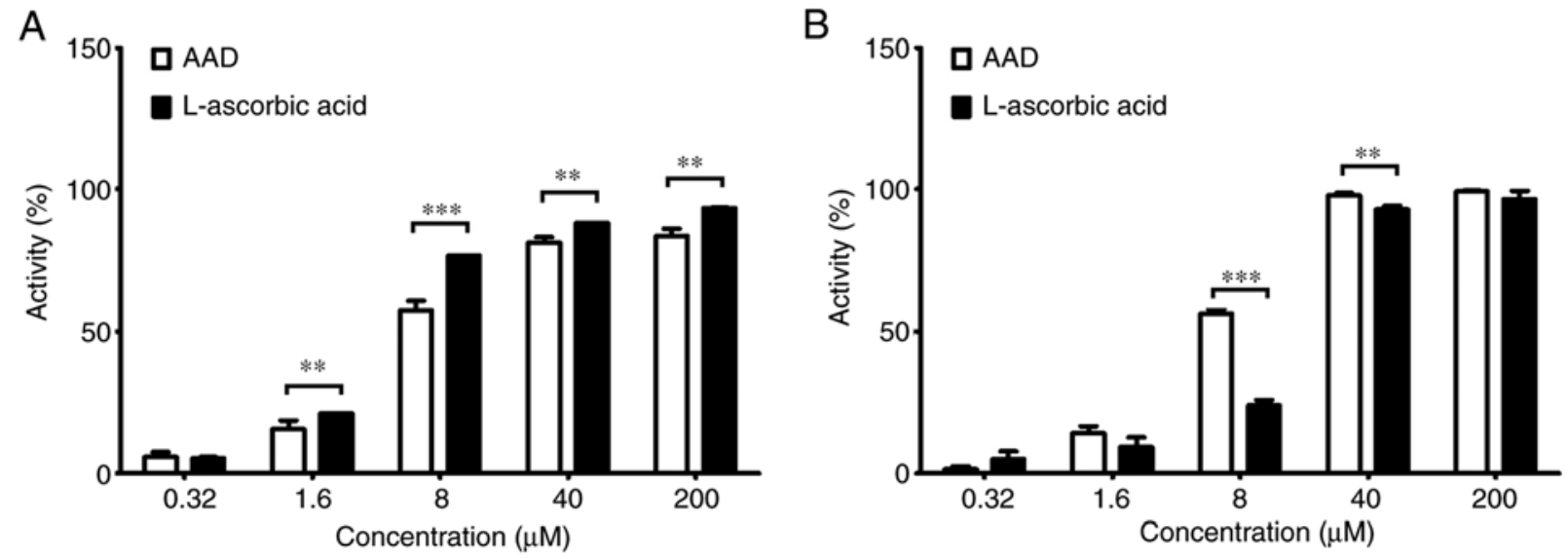

Figure 2. Antioxidant activities of AAD and L-ascorbic acid. (A) DPPH radical scavenging activity. (B) ABTS radical scavenging activity. Data are presented as the mean \pm standard deviation of $\geq 3$ independent experiments. ${ }^{* *} \mathrm{P}<0.01,{ }^{* * * *} \mathrm{P}<0.001 \mathrm{vs}$. L-ascorbic acid-treated group. AAD, acteoside from Abeliophyllum distichum; DPPH, 1,1-diphenyl-2-picryl hydrazyl; ABTS, 2,2'-azino-bis (3-ethylbenzothiazoline-6-sulfonic acid) diammonium salt.

A

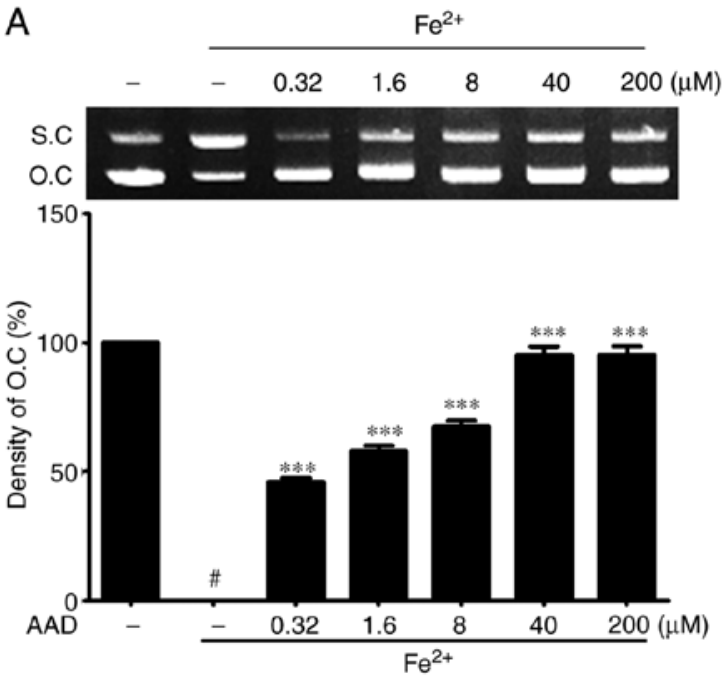

B

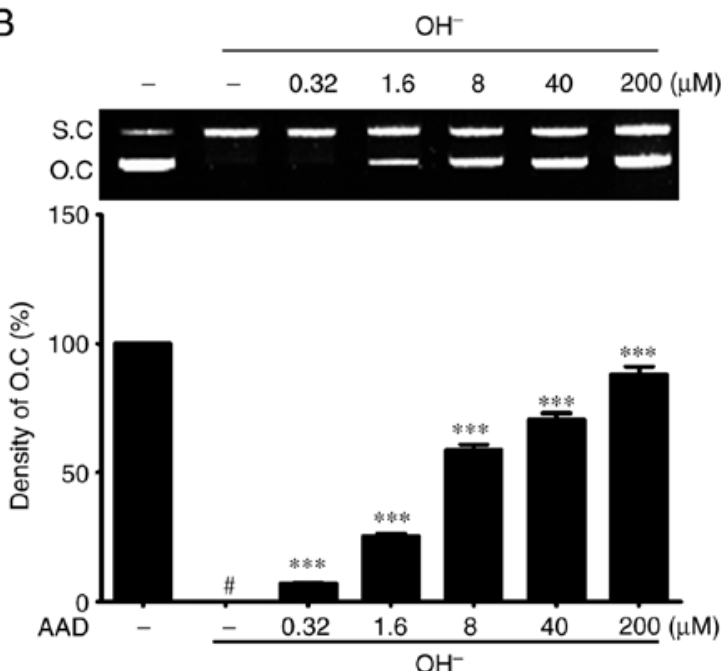

Figure 3. Protective effects of AAD on oxidative DNA damage using $\Phi X-174$ RF I plasmid DNA. (A) Fe ${ }^{2+}$-induced DNA damage. (B) OH- radical-induced DNA damage. Data are presented as the mean \pm standard deviation of $\geq 3$ independent experiments. ${ }^{\prime \prime} \mathrm{P}<0.05$ vs. untreated group; ${ }^{* * *} \mathrm{P}<0.001$ vs. the oxidative damage group without AAD (lane 2). AAD, acteoside from Abeliophyllum distichum; SC, supercoiled; OC, open circular.

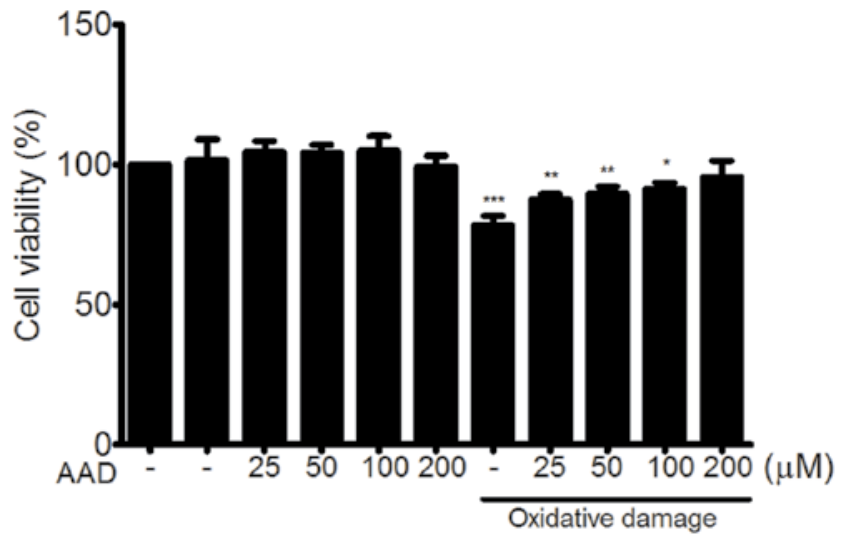

Figure 4 . AAD affects the viability of NIH 3 T3 cells. NIH 3 T3 cells were treated with various concentrations of AAD $(0-200 \mu \mathrm{M})$ for $24 \mathrm{~h}$ and cytotoxicity in the absence or presence of oxidative damage $(150 \mu \mathrm{M}$ $\mathrm{FeSO}_{4}+600 \mu \mathrm{M} \mathrm{H}_{2} \mathrm{O}_{2}$ ) was assessed using the alamarBlue ${ }^{\circledast}$ cell viability reagent. Data are presented as the mean $\pm \mathrm{SD}$ of $\geq 3$ independent experiments. ${ }^{*} \mathrm{P}<0.05,{ }^{* *} \mathrm{P}<0.01$ and ${ }^{* * *} \mathrm{P}<0.001$ vs. untreated group. $\mathrm{AAD}$, acteoside from Abeliophyllum distichum.
AAD inhibited $\mathrm{Fe}^{2+}$-induced oxidative DNA damage in a dose-dependent manner, as suggested by the significant OC band density increase at all concentrations, compared with the negative control $(47.14 \pm 1.64 \%$ at $0.32 \mu \mathrm{M}$ AAD vs. $97.66 \pm 3.41 \%$ at $200 \mu \mathrm{M}$; Fig. 3A). Additionally, AAD also significantly protected plasmid DNA from OH- radicals-induced oxidative damage in a dose-dependent manner $(7.09 \pm 0.25 \%$ at $0.32 \mu \mathrm{M}$ AAD vs. $88.05 \pm 3.09 \%$ at $200 \mu \mathrm{M}$; Fig. 3B). These results suggested that AAD could protect plasmid DNA from oxidative damage.

Cytotoxicity of AAD in NIH $3 T 3$ cells. To determine whether AAD had any cytotoxic effect, NIH 3T3 cells were cultured in AAD concentrations ranging between 25 and $200 \mu \mathrm{M}$, and cell viability was then assessed following $24-h$ incubation. AAD had no effect on cell viability. In oxidative damage conditions, AAD increased cell viability compared with untreated cells (Fig. 4).

AAD protects NIH $3 T 3$ cells against oxidative DNA damage. Western blotting assays suggested that, in the absence 
A

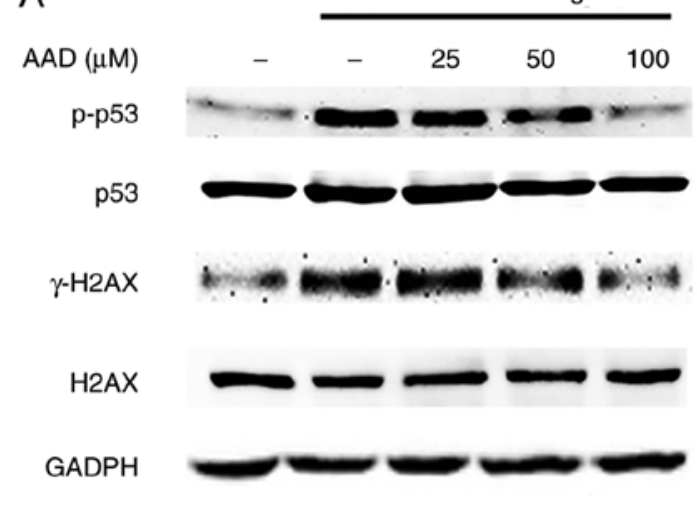

C

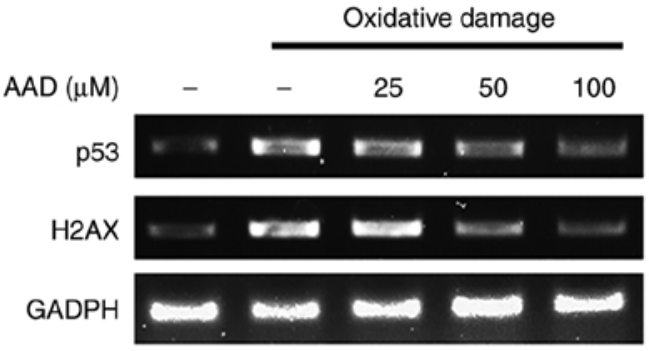

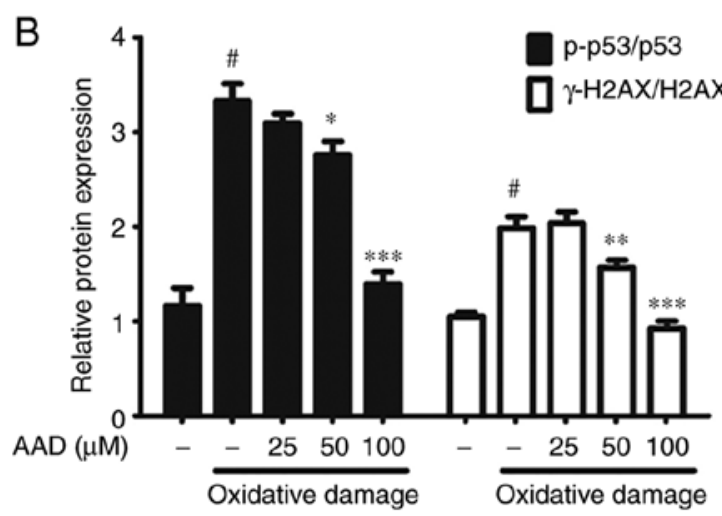

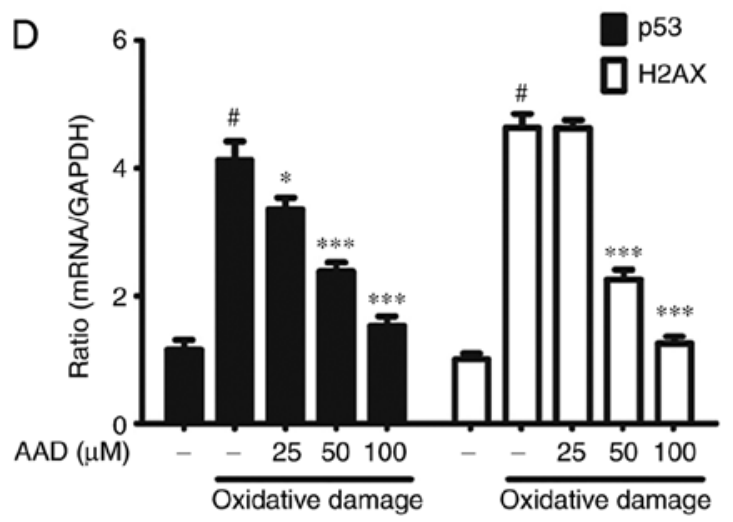

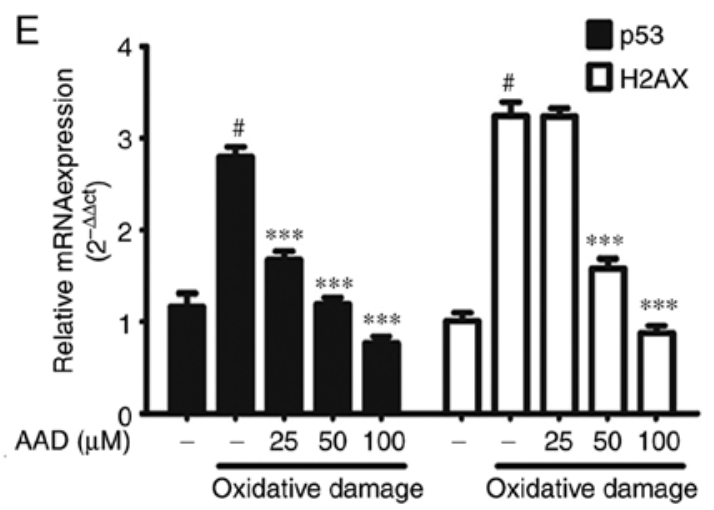

Figure 5. AAD protects NIH 3 T3 cells from oxidative DNA damage. (A) Western blots of p-p53, p53, $\gamma$-H2AX, H2AX and GAPDH in NIH 3 T3 cells treated with AAD $(25-100 \mu \mathrm{M})$ in the presence of oxidative damage $\left(150 \mu \mathrm{M} \mathrm{FeSO}_{4}+600 \mu \mathrm{M} \mathrm{H}_{2} \mathrm{O}_{2}\right)$ for $24 \mathrm{~h}$. (B) Densitometry of p-p53, p53, $\gamma-\mathrm{H} 2 \mathrm{AX}$ and $\mathrm{H} 2 \mathrm{AX}$ in NIH 3T3 cells. (C) DNA gel electrophoresis of p53 and H2AX genes in NIH 3T3 cells treated with AAD, and oxidative damage for $24 \mathrm{~h}$. (D) Semi-quantitative analysis of p53 and H2AX gene expression in NIH 3T3 cells. (E) Reverse transcription-quantitative PCR analysis of p53 and H2AX expression in NIH 3T3 cells. Data are presented as the mean \pm standard deviation of $\geq 3$ independent experiments; ${ }^{\#} \mathrm{P}<0.05$ vs. untreated group; ${ }^{*} \mathrm{P}<0.05,{ }^{* *} \mathrm{P}<0.01,{ }^{* * *} \mathrm{P}<0.001$ vs. oxidative damage group without $\mathrm{AAD}$ (the second bar). AAD, acteoside from Abeliophyllum distichum; $\mathrm{H} 2 \mathrm{AX}, \mathrm{H} 2 \mathrm{~A}$ histone family member $\mathrm{X} ; \mathrm{p} / \gamma$, phosphorylated.

of AAD, oxidative damage significantly increased phosphorylation of p-53 and H2AX in NIH 3 T3 cells. However, under oxidative damage conditions, the levels of p-p53 and $\gamma-\mathrm{H} 2 \mathrm{AX}$ were significantly reduced by treatment with AAD. This reduction in $\mathrm{p}$-p53 and $\gamma$-H2AX was dose-dependent (Fig. 5A and B). Additionally, gene expression levels of p53 and $\mathrm{H} 2 \mathrm{AX}$ followed the same pattern, as indicated by RT-semi-qPCR (Fig. 5C and D) and RT-qPCR (Fig. 5E).

Immunofluorescence staining of p-p53 and $\gamma-\mathrm{H} 2 \mathrm{AX}$ was also performed (Fig. 6). The levels of p-p53 and $\gamma$-H2AX increased following oxidative damage. However, p-p53 and $\gamma-\mathrm{H} 2 \mathrm{AX}$ levels were reduced in the presence of AAD compared with untreated oxidative damaged cells. These results suggested that $\mathrm{AAD}$ could regulate the expression of p-p53 and $\gamma$-H2AX.

\section{Discussion}

Due to the rarity of A. distichum Nakai, previous studies have focused on its ecological characterization, genomic sequencing and biological properties (35-40). Bremer et al (41) demonstrated that a number of plants in the Oleaceae family, such as the Abeliophyllum, Forsythia and Jasminum genera, contain acteoside. Although the potential bioactivities of acteoside may have important uses in industry and research, AAD remains poorly characterized. 
A
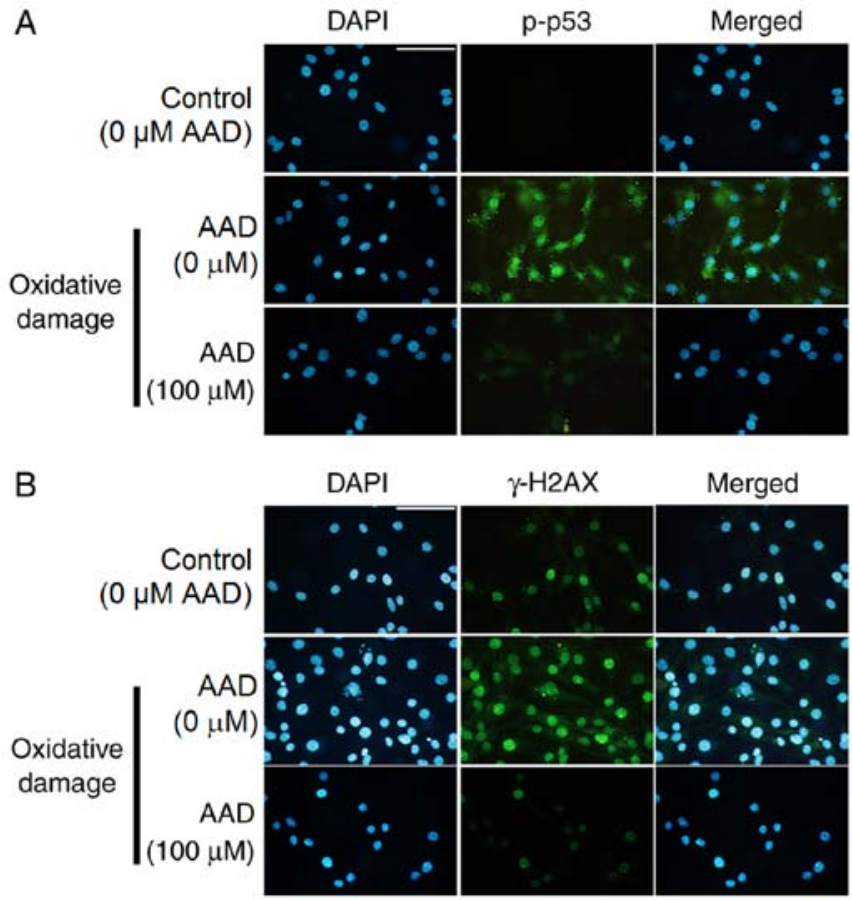

Figure 6. AAD regulates p-p53 and $\gamma-\mathrm{H} 2 \mathrm{AX}$ in NIH $3 \mathrm{~T} 3$ cells (A) Fluorescence microscopy shows expression of anti-p-p53 antibody in NIH $3 \mathrm{~T} 3$ cells treated for $24 \mathrm{~h}$ with $150 \mu \mathrm{M} \mathrm{FeSO}_{4}$ and $600 \mu \mathrm{M} \mathrm{H}_{2} \mathrm{O}_{2}$ (oxidative damage) in the presence or absence of $100 \mu \mathrm{M}$ AAD. Green, p-p53; Blue, DAPI. Scale bar, $40 \mu \mathrm{m}$. (B) Fluorescence microscopy shows expression of anti- $\gamma-\mathrm{H} 2 \mathrm{AX}$ antibody in NIH 3T3 cells treated for $24 \mathrm{~h}$ with $150 \mu \mathrm{M}$ $\mathrm{FeSO}_{4}$ and $600 \mu \mathrm{M} \mathrm{H}_{2} \mathrm{O}_{2}$ (oxidative damage) in the presence or absence of $100 \mu \mathrm{M}$ AAD. Green, $\gamma$-H2AX; Blue, DAPI. Scale bar, $40 \mu \mathrm{m}$. Control (0 $\mu \mathrm{M}$ AAD; no oxidative damage); AAD, acteoside from Abeliophyllum distichum; H2AX, H2A histone family member X; $/ \gamma$, phosphorylated; DAPI, 4,6-diamidino-2-phenylindole.

Several plant-sourced compounds, such as vitamin C, phenolics and flavonoids, can act as natural antioxidants by reacting with free radicals, chelating catalytic metals and scavenging oxygen $(42,43)$. Antioxidants suppress oxygen, electrons and hydrogen atoms that are generated during intracellular metabolism. They also protect cells against harmful effects of ROS and associated oxidative stress generated in aerobic organisms (44). For these reasons, numerous studies on the regulation of ROS and the role of natural antioxidants derived from plants have been conducted (45-47).

In the present study, HPLC and LC-MS analyses were carried out to characterize an AAD extract. The AAD sample had the same retention time and a similar UV spectrum compared with a standard acteoside. Additionally, based on LC-MS analysis, the AAD peak was observed at $623 \mathrm{~m} / \mathrm{z}\left(\mathrm{M}-\mathrm{H}^{-}\right)$, which coincided with the molecular weight of acteoside (48). Consequently, based on HPLC-PDA and LC-MS data, the AAD extract used in this study was identified as acteoside. Additionally, the effects of the antioxidant properties of AAD on oxidative DNA damage were also examined. Our previous studies suggested that $A$. distichum had potential antioxidant activities $(49,50)$. DPPH and ABTS radicals are the most common and most stable chromogens used to estimate antioxidant activity of biological materials. Furthermore, DPPH radical scavenging and ABTS radical cation decolorization assays can both be used to evaluate antioxidant activities in a relatively short time $(51,52)$. Oxidation of ABTS with potassium persulfate generates $\mathrm{ABTS}^{-+}$radical cations with the transfer of one electron. Under prolonged oxidative conditions, these radicals can generate di-cation $\mathrm{ABTS}^{2+}$ radicals $(53,54)$. In the present study, AAD scavenged both DPPH and ABTS radicals.

DNA damage leads to an irreversible covalent modification of the DNA molecule. This can occur through single- or double-strand breaks (DSBs) in the DNA sugar-phosphate backbone, disruption of the or N-glycosidic bonds linking nucleobases to the sugar, as well as chemical modification of nucleobase residues $(55,56)$. Oxidative DNA damage represents one of the most frequent consequences of exposure to exogenous environmental stimuli or endogenous genotoxic agents. These reactions are associated with the activity of ROS, such as hydroxyl radicals, superoxides, peroxides or single oxygen $(57,58)$. For instance, the oxidative DNA damage produced by the Fenton reaction plays a major role in the aging process, as well as several diseases, including Alzheimer's disease, cancer and multiple sclerosis (59-62). In the present study, the protective effects of AAD against oxidative DNA damage were evaluated using non-cellular and cellular models. A $\Phi X-174$ RF I plasmid DNA cleavage assay was conducted using $\mathrm{OH}$ radicals and $\mathrm{Fe}^{2+}$ ions. Hydrogen peroxide itself cannot directly oxidize DNA molecules, but can react with transition metals, such as $\mathrm{Fe}^{2+}$ to form $\mathrm{OH}^{-}$ radicals. These $\mathrm{OH}^{-}$radicals attack DNA structures, leading to sugar fragmentation, strand scission and base adducts (63). The $\mathrm{Fe}^{2+}$ ion is an essential transition metal element in humans. In the present study, AAD decreased oxidative DNA damage in a dose-dependent manner. Therefore, due to its scavenging capacity, AAD may prevent cell damage caused by $\mathrm{OH}$ - radicals and $\mathrm{Fe}^{2+}$ ions. This type of DNA damage is one of the most genotoxic types occurring in cells, either resulting in cell cycle arrest and DNA repair, or elimination of the injured cells. Appropriate cellular responses to DNA DSBs are important for tumor suppression and maintaining genetic stability $(64,65)$.

One of the first cellular responses to the introduction of DSBs is the phosphorylation of $\mathrm{H} 2 \mathrm{AX}$, a sensitive marker for DNA DSBs. DSBs induce phosphorylation of H2AX at its C-terminal serine residues (Ser136 and Ser139) (66). The phosphorylated formed of $\mathrm{H} 2 \mathrm{AX}$, called $\gamma-\mathrm{H} 2 \mathrm{AX}$, is detectable at the sites of the damage following the introduction of DSBs $(67,68)$. Therefore, $\gamma-\mathrm{H} 2 \mathrm{AX}$ plays a distinct role in the DNA damage response. Additionally, the p53 pathway is also a key effector of the DNA damage response and is activated by several stimuli that induce DNA lesions (69). The expression of phosphorylated p53 (p-p53) may represent a negative regulator of the cellular response to DNA damage (70). In the present study, AAD treatment reduced the phosphorylation of $\gamma$-H2AX and p-p53 in NIH 3T3 cells under oxidative damage conditions. Moreover, the expression levels of H2AX and p53 were also reduced by AAD treatment. Although several other possible mechanisms may also explain these observations, the present study identified a relationship between the antioxidant properties of AAD and inhibition of DNA damage. In conclusion, the present study demonstrated that AAD displayed antioxidant properties that could protect DNA against oxidative damage. 


\section{Acknowledgements}

Not applicable.

\section{Funding}

This research was supported by The Basic Science Research Program through The National Research Foundation of Korea funded by The Ministry of Education (grant no. NRF-2016R1D1A1B03934869).

\section{Availability of data and materials}

All data generated or analyzed during this study are included in this published article.

\section{Authors' contributions}

TWJ and JHP drafted the manuscript and performed the experiments. TWJ and JSC performed the experiments and data interpretation. TWJ contributed materials and analytical tools and helped in data analysis. TWJ, JSC and JHP designed the experiments, provided critical suggestions for the manuscript, and reviewed and revised the manuscript. All authors read and approved the final manuscript.

\section{Ethics approval and consent to participate}

Not applicable.

\section{Patient consent for publication}

Not applicable.

\section{Competing interests}

The authors declare that they have no competing interests.

\section{References}

1. Akerele O: Nature's medicinal bounty: Don't throw it away. In: World Health Forum 14: 390-395, 1993.

2. Omale $\mathrm{J}$ and Okafor PN: Comparative antioxidant capacity, membrane stabilization, polyphenol composition and cytotoxicity of the leaf and stem of Cissus multistriata. Afr J Biotechnol 7: 17, 2008

3. Hill AF: Economic Botany. McGraw-Hill, New York, NY, p560, 1952.

4. Edeoga HO, Okwu D and Mbaebie B: Phytochemical constituents of some Nigerian medicinal plants. Afr J Biotechnol 4: 685-688, 2005.

5. Valko M, Morris H and Cronin MT: Metals, toxicity and oxidative stress. Curr Med Chem 12: 1161-1208, 2005.

6. Schärer OD: Chemistry and biology of DNA repair. Angew Chem Int Ed Engl 42: 2946-2974, 2003.

7. Han HM, Kwon YS and Kim MJ: Antioxidant and antiproliferative activity of extracts from water chestnut (Trapa japonica Flerow). Hanguk Yakyong Changmul Hakhoe Chi 24: 14-20, 2016.

8. Roos WP, Thomas AD and Kaina B: DNA damage and the balance between survival and death in cancer biology. Nat Rev Cancer 16: 20-33, 2016.

9. Gilgun-Sherki Y, Rosenbaum Z, Melamed E and Offen D: Antioxidant therapy in acute central nervous system injury: Current state. Pharmacol Rev 54: 271-284, 2002.

10. Hamanaka RB and Chandel NS: Mitochondrial reactive oxygen species regulate cellular signaling and dictate biological outcomes. Trends Biochem Sci 35: 505-513, 2010
11. Simon HU,Haj-Yehia A and Levi-Schaffer F: Role of reactive oxygen species (ROS) in apoptosis induction. Apoptosis 5: 415-418, 2000.

12. Fernandez-CapetilloO,Lee A,Nussenzweig $M$ and Nussenzweig A: H2AX: The histone guardian of the genome. DNA Repair (Amst) 3: 959-967, 2004.

13. Stucki M, Clapperton JA, Mohammad D, Yaffe MB, Smerdon SJ and Jackson SP: MDC1 directly binds phosphorylated histone $\mathrm{H} 2 \mathrm{AX}$ to regulate cellular responses to DNA double-strand breaks. Cell 123: 1213-1226, 2005.

14. Cook PJ, Ju BG, Telese F, Wang X, Glass CK and Rosenfeld MG: Tyrosine dephosphorylation of $\mathrm{H} 2 \mathrm{AX}$ modulates apoptosis and survival decisions. Nature 458: 591-596, 2009.

15. Liu B, Chen Y and St Clair DK: ROS and p53: A versatile partnership. Free Radic Biol Med 44: 1529-1535, 2008.

16. Polyak K, Xia Y, Zweier JL, Kinzler KW and Vogelstein B: A model for p53-induced apoptosis. Nature 389: 300-305, 1997.

17. Sablina AA, Budanov AV, Ilyinskaya GV, Agapova LS, Kravchenko JE and Chumakov PM: The antioxidant function of the p53 tumor suppressor. Nat Med 11: 1306-1313, 2005.

18. Shibata A and Jeggo PA: DNA double-strand break repair in a cellular context. Clin Oncol (R Coll Radiol) 26: 243-249, 2014.

19. Paull TT, Rogakou EP, Yamazaki V, Kirchgessner CU, Gellert M and Bonner WM: A critical role for histone $\mathrm{H} 2 \mathrm{AX}$ in recruitment of repair factors to nuclear foci after DNA damage. Curr Biol 10: 886-895, 2000.

20. Ji K, Jang NY and Kim YT: Isolation of lactic acid bacteria showing antioxidative and probiotic activities from kimchi and infant feces. J Microbiol Biotechnol 25: 1568-1577, 2015.

21. Nakai T: Genus novum Oleacearum in Corea media inventum. Shokubutsugaku Zasshi 33: 153-154, 1919.

22. Oh H, Kang DG, Kwon TO, Jang KK, Chai KY, Yun YG, Chung HT and Lee HS: Four glycosides from the leaves of Abeliophyllum distichum with inhibitory effects on angiotensin converting enzyme. Phytother Res 17: 811-813, 2003.

23. Xiong Q, Hase K, Tezuka Y, Tani T, Namba T and Kadota S: Hepatoprotective activity of phenylethanoids from Cistanche deserticola. Planta Med 64: 120-125, 1998.

24. Schlesier K, Harwat M, Böhm V and Bitsch R: Assessment of antioxidant activity by using different in vitro methods. Free Radic Res 36: 177-187, 2002.

25. Xie J: Effect of ethanolic extract of Cistanche deserticola on the contents of monoamine neurotransmitters in rat brain. Chin Tradit Herbal Drugs 24: 417-419, 1993.

26. He ZD, Lau KM, Xu H-X, Li PC and Pui-Hay But P: Antioxidant activity of phenylethanoid glycosides from Brandisia hancei. J Ethnopharmacol 71: 483-486, 2000.

27. Li J, Wang PF, Zheng R, Liu ZM and Jia Z: Protection of phenylpropanoid glycosides from Pedicularis against oxidative hemolysis in vitro. Planta Med 59: 315-317, 1993.

28. Xiong Q, Kadota S, Tani T and Namba T: Antioxidative effects of phenylethanoids from Cistanche deserticola. Biol Pharm Bull 19: 1580-1585, 1996.

29. Zong G, He W, Wu G, Chen M, Shen X and Shi M: Comparisons between Cistanche deserticola Y.C. Ma and C.tubulosa (Schenk) Wight on Some Pharmacological Actions. Zhongguo Zhong Yao Za Zhi 21: 436-437, 1996 (In Chinese).

30. Bondet V, Brand-Williams W and Berset C: Kinetics and mechanisms of antioxidant activity using the DPPH. free radical method. Lebensm Wiss Technol 30: 609-615, 1997.

31. van den Berg R, Haenen GR, van den Berg $H$ and Bast A: Applicability of an improved Trolox equivalent antioxidant capacity (TEAC) assay for evaluation of antioxidant capacity measurements of mixtures. Food Chem 66: 511-517, 1999.

32. Jung Y and Surh Y: Oxidative DNA damage and cytotoxicity induced by copper-stimulated redox cycling of salsolinol, a neurotoxic tetrahydroisoquinoline alkaloid. Free Radic Biol Med 30: 1407-1417, 2001.

33. Livak KJ and Schmittgen TD: Analysis of relative gene expression data using real-time quantitative PCR and the $2^{-\Delta \Delta C T}$ method. Methods 25: 402-408, 2001.

34. Otterbein LE, Hedblom A, Harris C, Csizmadia E, Gallo D and Wegiel B: Heme oxygenase-1 and carbon monoxide modulate DNA repair through ataxia-telangiectasia mutated (ATM) protein. Proc Natl Acad Sci USA 108: 14491-14496, 2011.

35. Kang U, Chang CS and Kim YS: Genetic structure and conservation considerations of rare endemic Abeliophyllum distichum Nakai (Oleaceae) in Korea. J Plant Res 113: 127-138, 2000.

36. Kim NY and Lee HY: Effect of antioxidant and skin whitening of ethanol extracts from ultrasonic pretreated Abeliophyllum distichum Nakai. Hanguk Yakyong Changmul Hakhoe Chi 23: 155-160, 2015. 
37. Kim HW, Lee HL, Lee DK and Kim KJ: Complete plastid genome sequences of Abeliophyllum distichum Nakai (Oleaceae), a Korea endemic genus. Mitochondrial DNA B Resour 1: 596-598, 2016.

38. Park J, Kim Y, Xi H, Jang T and Park JH: The complete chloroplast genome of Abeliophyllum distichum Nakai (Oleaceae) cultivar Ok Hwang 1ho: Insights of cultivar specific variations of A. distichum. Mitochondrial DNA B Resour 4: 1640-1642, 2019.

39. Min J, Kim Y, Xi H, Jang T, Kim G, Park J and Park JH: The complete chloroplast genome of a new candidate cultivar, Sang Jae, of Abeliophyllum distichum Nakai (Oleaceae): Initial step of A. distichum intraspecies variations atlas. Mitochondrial DNA B Resour 4: 3716-3718, 2019.

40. Park J, Min J, Kim Y, Xi H, Kwon W, Jang T, Kim G and Park JH: The complete chloroplast genome of a new candidate cultivar, Dae Ryun, of Abeliophyllum distichum Nakai (Oleaceae). Mitochondrial DNA B Resour 4: 3713-3715, 2019.

41. Bremer B, Bremer K, Heidari N, Erixon P, Olmstead RG Anderberg AA, Källersjö M and Barkhordarian E: Phylogenetics of asterids based on 3 coding and 3 non-coding chloroplast DNA markers and the utility of non-coding DNA at higher taxonomic levels. Mol Phylogenet Evol 24: 274-301, 2002.

42. Pisoschi AM, Cheregi MC and Danet AF: Total antioxidant capacity of some commercial fruit juices: Electrochemical and spectrophotometrical approaches. Molecules 14: 480-493, 2009.

43. Prasad KN, Chew LY, Khoo HE, Kong KW, Azlan A and Ismail A Antioxidant capacities of peel, pulp, and seed fractions of Canarium odontophyllum Miq. fruit. J Biomed Biotechnol 2010: 871379,2010

44. Sies H: Strategies of antioxidant defense. Eur J Biochem 215: 213-219, 1993

45. Devasagayam TP, Tilak JC, Boloor KK, Sane KS, Ghaskadbi SS and Lele RD: Free radicals and antioxidants in human health: Current status and future prospects. J Assoc Physicians India 52: 794-804, 2004

46. Alfadda AA and Sallam RM: Reactive oxygen species in health and disease. J Biomed Biotechnol 2012: 936486, 2012.

47. Asif M: Chemistry and antioxidant activity of plants containing some phenolic compounds. Chem Int 1: 35-52, 2015.

48. Blazics B, Alberti Á,Kursinszki L, Kéry Á, Béni S and Tölgyesi L: Identification and LC-MS-MS determination of acteoside, the main antioxidant compound of Euphrasia rostkoviana, using the isolated target analyte as external standard. J Chromatogr Sci 49: 203-208, 2011.

49. Ahn J and Park JH: Effects of Abeliophyllum distichum Nakai flower extracts on antioxidative activities and inhibition of DNA damage. Korean J Plant Resour 26: 355-361, 2013.

50. Park JH: Antioxidant activities and inhibitory effect on oxidative DNA damage of extracts from Abeliophylli distichi Folium. Korea J Herbology 26: 95-99, 2011.

51. SieniawskaE, Baj T and Głowniak K: Influence of the preliminary sample preparation on the tannins content in the extracts obtained from Mutellina purpurea. Ann UMCS Sect 1500: 47-54, 2010.

52. Luís Â, Domingues F, Gil C and Duarte AP: Antioxidant activity of extracts of Portuguese shrubs: Pterospartum tridentatum, Cytisus scoparius and Erica spp. J Med Plants Res 3: 886-893, 2009.

53. Venkatasubramanian L and Maruthamuthu P: Kinetics and mechanism of formation and decay of 2,2'-azinobis-(3-ethylbenzothiazole-6-sulphonate) radical cation in aqueous solution by inorganic peroxides. Int J Chem Kinet 21: 399-421, 1989.
54. Branchi B, Galli C and Gentili P: Kinetics of oxidation of benzyl alcohols by the dication and radical cation of ABTS. Comparison with laccase-ABTS oxidations: An apparent paradox. Org Biomol Chem 3: 2604-2614, 2005.

55. Gates KS: An overview of chemical processes that damage cellular DNA: Spontaneous hydrolysis, alkylation, and reactions with radicals. Chem Res Toxicol 22: 1747-1760, 2009.

56. Sancar A and Sancar GB: DNA repair enzymes. Annu Rev Biochem 57: 29-67, 1988

57. Cowan JA: Chemical nucleases. Curr Opin Chem Biol 5: 634-642, 2001

58. Vacek J, Mozga T, Cahová K, Pivoňková H and Fojta M: Electrochemical sensing of chromium-induced DNA damage: DNA strand breakage by intermediates of chromium (VI) electrochemical reduction. Electroanalysis. Int J Devoted Fundam Pract Asp Electroanalysis 19: 2093-2102, 2007.

59. Kanvah S and Schuster GB: One-electron oxidation of DNA: The effect of replacement of cytosine with 5-methylcytosine on long-distance radical cation transport and reaction. J Am Chem Soc 126: 7341-7344, 2004.

60. Demple B and Harrison L: Repair of oxidative damage to DNA: Enzymology and biology. Annu Rev Biochem 63: 915-948, 1994.

61. Poulsen HE, Prieme H and Loft S: Role of oxidative DNA damage in cancer initiation and promotion. Eur J Cancer Prev 7: 9-16, 1998.

62. Hasty P and Vijg J: Aging. Genomic priorities in aging. Science 296: 1250-1251, 2002

63. Hutchinson F: Chemical changes induced in DNA by ionizing radiation. Prog Nucleic Acid Res Mol Biol 32: 115-154, 1985.

64. Bennett CB, Lewis AL, Baldwin KK and Resnick MA: Lethality induced by a single site-specific double-strand break in a dispensable yeast plasmid. Proc Natl Acad Sci USA 90: 5613-5617, 1993.

65. Mills KD, Ferguson DO and Alt FW: The role of DNA breaks in genomic instability and tumorigenesis. Immunol Rev 194: 77-95, 2003.

66. Rogakou EP, Pilch DR, Orr AH, Ivanova VS and Bonner WM: DNA double-stranded breaks induce histone $\mathrm{H} 2 \mathrm{AX}$ phosphorylation on serine 139. J Biol Chem 273: 5858-5868, 1998.

67. Celeste A, Fernandez-Capetillo O, Kruhlak MJ, Pilch DR, Staudt DW, Lee A, Bonner RF, Bonner WM and Nussenzweig A: Histone H2AX phosphorylation is dispensable for the initial recognition of DNA breaks. Nat Cell Biol 5: 675-679, 2003.

68. Sedelnikova OA, Pilch DR, Redon C and Bonner WM: Histone $\mathrm{H} 2 \mathrm{AX}$ in DNA damage and repair. Cancer Biol Ther 2: 233-235, 2003.

69. Phillips ER and McKinnon PJ: DNA double-strand break repair and development. Oncogene 26: 7799-7808, 2007.

70. Kastan MB, Onyekwere O, Sidransky D, Vogelstein B and Craig RW: Participation of $\mathrm{p} 53$ protein in the cellular response to DNA damage. Cancer Res 51: 6304-6311, 1991.

This work is licensed under a Creative Commons Attribution-NonCommercial-NoDerivatives 4.0 International (CC BY-NC-ND 4.0) License. 